\title{
Mechanical and Micrography Analysis of Armour Plate Weldment Using Tungsten Inert Gas and Oxy-Acetylene Welding Methods
}

Obinna Anayo Osuchukwu ( $\sim$ oao1800004.pme@buk.edu.ng)

Bayero University

Emmanuel Obiora AGBOGU

Mechanical Engineering Department Nigerian Defence Academy

Danladi King GARBA

Mechanical Engineering Department Nigerian Defence Academy

Jacob Olaitan AKINDAPO

Mechanical Engineering Department Nigerian Defence Academy

\section{Research Article}

Keywords: Armour plate, Coarse grain, Ferrite, Micrography, Weldment

Posted Date: December 29th, 2021

DOI: https://doi.org/10.21203/rs.3.rs-1192540/v1

License: (a) (i) This work is licensed under a Creative Commons Attribution 4.0 International License. Read Full License 


\section{Abstract}

Defence Industries Corporation of Nigeria (DICON) has compared the effect of Tungsten Inert Gas (TIG) and Oxy-Acetylene welding methods on microstructural and some mechanical properties of Armour plate for the modification of military troop carriers. The optical emission spectrometer (OES) at DICON was used to analyse the chemical composition of the armour plate strip. It was then machined and cut to various test piece dimensions for both welding processes, following which the weldment samples were subjected to post-weld mechanical tests (tensile, impact, and hardness) and metallographic examination. The samples were then welded according to the procedure outlined in this study. The fundamental composition of armour plates was preserved in the samples. When compared to Oxy-Acetylene (OA) welding, Tungsten Inert Gas (TIG) welding produced better results, with an average ultimate strength (UTS) of $603.52 \mathrm{MPa}$ and an impact strength of $10.53 \mathrm{~J}$. In addition, the TIG analysis hardness strength for the source material, heat affected zone (HAZ), and weldment sample is 510.3, 502, and 511-HV, respectively. At x200 magnification, the micrography of the TIG weldment revealed a small coarse grain size of ferrite and larger areas of pearlite.

\subsection{Introduction}

Welds are blamed for a large number of manufacturing failures, either directly or indirectly, due to inhomogeneity on the weldment, stress concentration, residual stress, presence of contaminants, and other factors that make it the weakest portion [1]. Nonetheless, one of the welding processes is used to maintain a large number of failed machineries in industries, and its success is determined by a number of factors, including the weldability of the material, the type of impairment, the availability of an appropriate welding method, the likelihood of performing pre-heating or post-weld heat treatment, and postrepair inspection using non-destructive testing (NDT) procedures [1]. Welding is a method of joining two or more pieces that are similar to portions of the same or different materials in order to achieve a broad union. Heat and pressure are frequently used to do this [1,2].

Armour steel panels have been used in military vehicles in recent years to reduce vehicle weight and improve ballistic performance [3]. These low-alloy steels have good mechanical properties, such as high strength, increased notch toughness, and moderate hardness, due to the presence of a well-hardened martensitic structure [4]. In the manufacture of military vehicles, shielded metal arc welding (SMAW) and flux cored arc welding (FCAW) were commonly used. The weld and heat-affected zone (HAZ) microstructural features will have a significant impact on the ballistic performance of the joints. The strong resistance to projectile infiltration is widely recognized as ballistic ability [5,6]. In general, the tougher the steel, the stronger the infiltration resistance [7]. Various welding procedures have been effectively produced by a number of researchers $[8,9]$ to prevent joint failure and improve an aim's penetrating immunity. The ballistic resistance was increased by sandwiching hard-facing alloy in between soft welds using the classical SMAW process, according to Madhusudhan Reddy et al. [10].

Great-hardness quenched and tempered steels are employed in armour applications where projectile resistance is desired [4,5]. Heat-affected-zone (HAZ) unstiffening occurs when these steels are not protected from weld thermal series, resulting in a loss in ballistic performance. The goal of the weld thermal series, which is the behaviour of the welding technique, is to determine the degree of unstiffening in the HAZ. The unstiffening properties are based on the kinetics of the steel's phase shifts and are a function of the steel's chemistry [11-14]. Increased welding heat results in a wider lenient heat-affected zone, according to Reddy et al. [14], and the ballistic action is inversely proportional to the width of the lenient HAZ [13,14]. While demonstrating the welding procedure for military armour steel joints using gas metal arc welding (GMAW), David Maszuerarobledo et al [15] noted that while a specific grade of armour plate had been determined to be effective in previous studies by the National University of Colombia, a procedure utilizing a specific filler rod was recommended due to the special requirement for certification for any welder hoping to undertake this grade of welding. He conducted a welding practice despite the lack of ballistic tests, demonstrating that arc welding with a specified filler metal and copper backing is quite suitable for welding a military armour plate.

Almost all of the Nigerian military's troop-carrying vehicles are soft-skinned vehicles with little armour protection. The extent of insurgency and urban warfare in Nigeria necessitates more protection for combatants. The Defence Industries Cooperation of Nigeria (DICON) is currently working to upgrade some softskinned vehicles to armoured vehicles by replacing body panels with armour plates using available resources and methods. However, the initial effort did not consider any scientific or standard parameters when deciding which welding method to use, but rather did so based on the convenience of the available equipment. As a result, early failures at the joints occurred frequently, which was not safe enough to protect the crew. The current research examines the mechanical effectiveness of oxy-acetylene (OA) and tungsten inert gas (TIG) welding on armour plate weld joints in order to improve bullet resistance and prevent welded joint failure.

\subsection{Experimental Procedure}

The parent metal composition, heat treatment, welding technique, and metallographic procedures employed are all detailed in the following sections.

\subsection{Parent Metal}

The parent metal (Figure 1a) used in this investigation is a quenched and tempered high-strength low-alloy steel with the composition reported in Table 1 (Ballistic Steel Domex type-pro 500 BS Eng. 1522 standard 3x1.5x4 obtained from Columbia). The steel is heat treated by first austenitizing it at $900^{\circ} \mathrm{C}$, then air cooling it and tempering it at $250^{\circ} \mathrm{C}$. In this stage, the parent metal's microstructure is acicular martensite (Figure $1 \mathrm{~b}$ ). In this situation, the parent metal has a hardness of 490 to 520 VPN.

Table 1: Parent metal composition 


\begin{tabular}{|lllllllllllllllllll}
\hline Element & $\mathrm{C}$ & $\mathrm{Si}$ & $\mathrm{Mn}$ & $\mathrm{P}$ & $\mathrm{S}$ & $\mathrm{Ni}$ & $\mathrm{Cr}$ & $\mathrm{Mo}$ & $\mathrm{Cu}$ & $\mathrm{Co}$ & $\mathrm{Al}$ & $\mathrm{Pb}$ & $\mathrm{W}$ & $\mathrm{Ti}$ & $\mathrm{V}$ & $\mathrm{Sn}$ & $\mathrm{Fe}$ & \\
\hline Weight (\%) & 1.85 & 4.79 & 1.21 & 0.30 & 0.15 & 7.15 & 2.92 & 4.17 & 1.41 & 0.33 & 5.73 & 0.05 & 4.78 & 0.09 & 0.30 & 0.12 & 64.70 \\
\hline
\end{tabular}

\section{$2.2 \quad$ Welding}

Two welding procedures were tested to see how they affected the degree of HAZ unstiffening and, as a result, the mechanical impact. Oxy-acetylene (OA) and tungsten inert gas (TIG) welding are the two welding processes employed. A $1.6 \mathrm{~mm}$ gauge filler electrode is among the TIG equipment used. Table 2 shows the filler wire composition for OA welding as well as the TIG electrode used. Table 3 lists the welding constraints in detail. For both welding processes, the following procedures and preparations were followed in order: The armour plate strips were chopped into acute angles and flat plates, then chamfered grooves were added to prepare for double v-butt welding. The samples were edge prepared in order to achieve deep penetration and eliminate welding errors. To produce exceptionally smooth faces, the bevelled faces were carefully ground and cleaned of all dirt. For stable welding, the plates were set about 2 mm apart on a flat surface, and the welding was done in the rightward direction (backward techniques). The filler wire (electrodes) in TIG conducts currents through an electric holder to fuse the armour plate samples, which are encased in an inert shielding gas-argon-to protect both the electrode and the weld pool from the harmful effects of ambient air gases. In the case of oxy-acetylene, acetylene gas is combined with oxygen in a gas welding torch and then burned at the torch tip to create a flame hot enough to melt the armour plate samples. To fill the area and bond the two plates together, weld metals from both processes were employed. A power file was used to remove the splatters and uneven surfaces. Various mechanical property tests and metallographic analyses were performed on specimens from both welding procedures. The welded metals for the different welding processes are shown in Figures 2 (a) and (b).

Table 2: Composition of welding methods accessories

\begin{tabular}{|c|c|c|c|c|c|c|c|c|c|c|c|c|c|c|c|c|c|c|}
\hline \multirow[t]{2}{*}{$\mathbf{S} / \mathbf{N}$} & \multirow[t]{2}{*}{ Specimen } & \multicolumn{17}{|c|}{ Elements and Weight (\%) } \\
\hline & & $\mathrm{C}$ & $\mathrm{Si}$ & $\mathrm{Mn}$ & $P$ & $S$ & $\mathrm{Ni}$ & $\mathrm{Cr}$ & Mo & $\mathrm{Cu}$ & Co & $\mathrm{Al}$ & $\mathrm{Pb}$ & W & $\mathrm{Ti}$ & V & Sn & $\mathrm{Fe}$ \\
\hline 1 & $\begin{array}{l}\text { TIG } \\
\text { Electrode }\end{array}$ & 0.17 & 3.10 & 1.63 & 0.05 & 0.34 & 7.76 & 16.68 & 2.01 & 0.11 & 0.66 & 0.08 & 0.05 & 2.56 & 0.06 & 0.01 & 0.30 & 64.43 \\
\hline 2 & $\begin{array}{l}\text { Oxy- } \\
\text { Acetylene }\end{array}$ & 0.11 & 1.50 & 2.50 & 0.55 & 0.50 & 2.20 & 4.20 & 0.02 & 0.08 & 0.65 & 3.6 & 0.03 & 0.04 & 0.07 & 0.03 & 0.30 & 83.62 \\
\hline & $\begin{array}{l}\text { Filler } \\
\text { Wire }\end{array}$ & & & & & & & & & & & & & & & & & \\
\hline
\end{tabular}

\subsection{Mechanical Testing}

\subsubsection{Hardness Test}

After polishing the samples and placing them on the test bed, which was raised to be closer to the indenter, a specific steep pointer was used to indent them for the Vickers Hardness Test. The load $(10 \mathrm{~kg})$ is then placed on the hanger while the lever is engaged, and when the required load is placed, the lever is released. It is allowed to descend for 15 seconds into the sample before being removed for examination, measurement, and recording. The average diameter of three imprint diameters taken at right angles was measured, and the average diameter was used to calculate the Brinnel Hardness Number [11]. The HAZ was used to create these impressions. This equation (1) was used to calculate the BHN [16]:

$$
B H N=\frac{2 P}{\pi D\left(D-\sqrt{\left.D^{2}-d^{2}\right)}\right.}
$$

Where "P" represents the load, "D" represents the indenter's diameter, and "d" represents the average indentation reading. Both welding procedures were subjected to the same test.

Table 3: Welding constraints 


\begin{tabular}{|ll|}
\hline Tungsten Inert Gas Welding process & \\
Welding current $(\mathrm{A})$ & 250 \\
Arc Voltage $(\mathrm{V})$ & 220 \\
Welding speed $\left(\mathrm{mm}^{-1} \mathrm{~min}^{-1}\right)$ & 60 \\
Electrode & W-2\% Thorium \\
Electrode Polarity & DCSP \\
Welding technique & Backward \\
Arc gap (mm) & 2 \\
Shield gas & Argon \\
Preheat & None \\
& \\
Oxy-acetylene welding process & \\
Temperature & $3100^{\circ} \mathrm{C}$ \\
Gas & Oxygen and acetylene \\
Arc gap (mm) & 2 \\
Preheat & None \\
\hline
\end{tabular}

\subsubsection{Impact Test}

The machined specimen (sub-size plate $70 \mathrm{~mm}$ long, $10 \mathrm{~mm}$ wide, $5 \mathrm{~mm}$ thick, and $2 \mathrm{~mm}$ deep notch (ISTM A370)) was supported horizontally on an anvil at its two ends and struck on the opposite face of the notch by a pendulum in the lzod test. At the same temperature, the three specimens were tested, and the findings were averaged and reported [17-19].

\subsubsection{Tensile Test}

The test begins with the test specimen being clamped in the clamping chuck and the measuring gauge being preloaded by a few millimetres. Turning the crank handle while watching the gauge's indicator as the specimen slowly stretches till it breaks produces force. Data was gathered and computations were performed. The specimen was cut into a rectangular segment along the gauge length of both ends, with enough length and a smooth surface to be grasped securely throughout the testing process. The specifications employed were $110 \mathrm{~mm}$ in length and $15 \mathrm{~mm}$ in width, as per International Standard Test Methods for Tensile Testing of Metallic Materials (ISTM) [20,21]. The formula for calculating the Ultimate Tensile Strength is given by equation 2 [22]:

$$
\sigma_{U T S}=\frac{P_{\max }}{A_{o}}
$$

\subsection{Metallographic Analysis}

Each metallographic sample's surface was ground with silicon carbide grinding paper grits of 120 to 300 and polished with a polymate polishing machine by wetting the polishing cloth resting on the polishing wheel with alumina polishing powder dissolved in distilled water. Following that, the samples were etched with 2 percent picral (2gram picric acid in $100 \mathrm{ml}$ ethyl alcohol) and then washed under running water with cotton wool to remove any contaminants from the surface of the manufactured samples. The microstructure of the sample was investigated using a photographic visual metallurgical microscope, model number NJF-120A, after it was dried with a blower and placed on the stage for analysis.

\subsection{Results And Discussions}

The microstructure, mechanical tests, and metallographic analysis results are presented in the following sections.

\subsection{Metallographic}

At x200 magnification, the parent metal micrography consists of ferrite in a pearlite matrix with a fine grain size (Figure 1). At x200 magnification, the micrography of the TIG welding method's heat affected zone (HAZ) has a coarse grain size of ferrite with small patches of pearlite (Figure 3a), whereas the micrography of the TIG weld region has a small coarse grain size of ferrite and more patches of pearlite (Figure 3b).

At x200 magnification, the micrography of the heat affected zone (HAZ) of the Oxy-Acetylene welding method shows pearlite distributed evenly in the ferrite matrix in a fairly coarse grain size (Figure 3c), whereas the micrography of the oxy-acetylene weldment shows pearlite in the ferrite matrix with a coarser grain size (Figure 3d). 
The percentage composition of the principal components contained in the TIG weldment is as follows, according to the results of the chemical analysis: 3.97 \% W, 0.13 \% Ti, 0.33 \% V, 0.14\% Sn, 57.62\% Fe, 2.01 \% C, 5.87 \% Si, 1.39 \% Mn, 0.29 \% P, 0.15 \% S, 7.59 \% Ni, 6.56\% Cr, 4.79 \% Mo, 1.48 \% Cu, 7.37 \% Al, $0.07 \% \mathrm{~Pb}$. As a result, a low-carbon steel alloy was utilized as the tungsten electrode [23-25]. When alloying elements such as Nikel, Chromium, and Molybdenum are employed for welding, the chemical characteristics of the weldments increase. As a result, the weldment has high temperature resistance, toughness, wear resistance, and hardness due to the combination of Nikel, Chromium, and Molybdenum [24]. The impact and tensile strengths of the weldments are improved as a result as well as projectile resistance according Ref [12].

The following percentage composition of main elements is revealed by chemical analysis of the oxy-acetylene weldment: $1.99 \% \mathrm{C}, 3.95 \% \mathrm{Si}, 1.90 \% \mathrm{Mn}$, $0.60 \% \mathrm{P}, 0.40 \% \mathrm{~S}, 3.37 \% \mathrm{Si}, 3.06 \% \mathrm{Cr}, 1.96 \% \mathrm{Mo}, 1.36 \% \mathrm{Cu}, 4.27 \% \mathrm{Al}, 0.06 \% \mathrm{~Pb}, 2.98 \% \mathrm{~W}, 0.13 \% \mathrm{Ti}, 0.34 \% \mathrm{~V}, 0.14 \% \mathrm{Sn}, 73.33 \% \mathrm{Fe}$. Because the carbon content of this weldment is smaller than that of a TIG weldment, the weldment has a lesser hardness and toughness. Furthermore, the presence of substantially higher phosphorus and sulphur, which have strong embrittling influences that cause metal to split when forged, e.g. manganese sulphide (Mn S) or ferrous sulphide (Fe S), has a melting point, resulting in heated and cooled shortness. Because of its poor resistance to indentation, the weldment's mechanical qualities, such as impact and tensile strength, are weakened, and it absorbs a smaller amount of energy to fracture $[21,24,26]$.

The major alloying element that controls the hardness of steel alloys is carbon. When the carbon content of the armour steel is greater than 0.37 wt percent C, a hardness greater than $500 \mathrm{VHN}$ can be achieved [6]. The silicon content of the steel has a significant impact on the martensite's stability during tempering, as it prevents the martensite from softening at higher temperatures. It also appears to improve the cementite's resistance to dynamic coarsening under ballistic impact [34]. The chemical activity of carbon is reduced by silicon, which increases the stability of martensite [35].

\subsection{Tensile Tests Results}

The weldment and tensile crack specimens for both welding methods respectively are shown in Figures (3a) - (d).

The TIG weldment's average ultimate tensile strength (UTS) was $603.52 \mathrm{MPa}$ (Table 4a), which is quite strong. As a result, this is a hint that this welding method has a high toughness, which will help the joint last longer before failing. According to Refs [27-29], this UTS complies with the most recent criteria for military and security applications. The average ultimate tensile strength (UTS) of the oxy-acetylene weldment was $261.44 \mathrm{MPa}$ (Table $4 \mathrm{~b}$ ), which is low and suggests a shorter time to failure at the weldment, which translates to low toughness. Welding temperature or duration may be to blame for the lower value. This number falls short of the most recent minimum tensile criterion for military uses. As a result, TIG welding is recommended for this application. Dikshit et al. [30] found that the effect of a plate's hardness on its ballistic behaviour was dependent on whether the stress condition was primarily plane strain or plane stress, whereas Sorensen et al. [31] discovered that, despite their lower hardness, nitrogen alloyed austenitic steels had similar ballistic behaviour to high strength armour steel. As a result, the effect of hardness on the ballistic behaviour of armour steels is not always clear. It is dependent on the role of the impact velocity and the armour plate thickness. So, in the case of a thinner plate's behaviour under high strain rates, the ability to counteract ballistic damage is based on hardness in the first instance, but the ability to distort plastically in a large volume around the effect zone develops the cause [6].

Table 4a: Tensile test results for TIG welding method

\begin{tabular}{|c|c|c|c|c|c|c|c|c|}
\hline Samples & Width (mm) & Thickness (mm) & Area $\left(\mathrm{mm}^{2}\right)$ & $\begin{array}{l}\text { Load } \\
(\mathrm{KN})\end{array}$ & $\begin{array}{l}\text { Load } \\
(\mathrm{N})\end{array}$ & Gauge Length $(\mathrm{mm})$ & $\begin{array}{l}\text { UTS } \\
\text { (MPa) }\end{array}$ & $\begin{array}{l}\text { Average } \\
\text { UTS (MPa) }\end{array}$ \\
\hline 1 & 10.2 & 6.2 & 63.24 & 28.5 & 28500 & 60 & 450.66 & \multirow[t]{3}{*}{603.52} \\
\hline 2 & 10.2 & 6.2 & 63.24 & 41.50 & 41500 & 60 & 656.23 & \\
\hline 3 & 10.2 & 6.2 & 63.24 & 44.50 & 44500 & 60 & 703.67 & \\
\hline
\end{tabular}

Table 4b: Tensile test results for OA welding method

\begin{tabular}{|lllllllll|}
\hline Samples & Width $(\mathrm{mm})$ & Thickness $(\mathrm{mm})$ & Area $\left(\mathrm{mm}^{2}\right)$ & $\begin{array}{l}\text { Load } \\
(\mathrm{KN})\end{array}$ & $\begin{array}{l}\text { Load } \\
(\mathrm{N})\end{array}$ & $\begin{array}{l}\text { Gauge Length }(\mathrm{mm}) \\
\text { UTS }\end{array}$ & $\begin{array}{l}\text { Average UTS }(\mathrm{MPa}) \\
(\mathrm{MPa})\end{array}$ \\
\hline 2 & 10.2 & 6.2 & 63.24 & 11.2 & 11200 & 60 & 177.10 & 261.44 \\
\hline 3 & 10.2 & 6.2 & 63.24 & 18.4 & 18400 & 60 & 290.96 \\
\hline
\end{tabular}

\subsection{Impact Strength Results}

Figures 4 (a) - (c) illustrate the impact crack outcomes on the parent metal, TIG welded joint, and OA welded joint specimens for both welding procedures (c).

For each welding method, three impact loading results were taken. The average impact energy for the parent metal, TIG, and Oxy-acetylene weldment was $15.70 \mathrm{~J}, 10.53 \mathrm{~J}$, and $6.46 \mathrm{~J}$, respectively. According to these findings, the TIG weldment impact energy is similar to that of the parent metal (control), implying that TIG welding has more weldment toughness to absorb projectile impact than OA welding. The armour plate material's average impact loading 
energy of $15.70 \mathrm{~J}$ demonstrates that it is an appropriate material for use in the fabrication of armoured vehicle body panels [32]. The impact strength results are shown in Tables $5(\mathrm{a})$ - (c). Figures $6(\mathrm{a})$ and (b) is the graphical comparison of the UTS and Hv results. From the graphs, the TIG welding showed better results than OA welding method.

Table 5a: Impact strength results for the parent metal

\begin{tabular}{|c|c|c|c|c|c|c|c|}
\hline Samples & Width (mm) & Thickness (mm) & Area $\left(\mathrm{mm}^{2}\right)$ & Notch $(\mathrm{mm})$ & $\begin{array}{l}\text { Energy } \\
\text { (ft lb) }\end{array}$ & Energy $(J)$ & Average Energy ( $(J)$ \\
\hline 1 & 15.0 & 6.2 & 93 & 5.5 & 11.6 & 15.7 & 15.7 \\
\hline 2 & 15.2 & 6.2 & 94.2 & 5.5 & 11.7 & 15.8 & \\
\hline 3 & 15.5 & 6.2 & 96.1 & 5.5 & 11.5 & 15.6 & \\
\hline
\end{tabular}

Table 5b: Impact strength results for the TIG welding

\begin{tabular}{|llllllll|}
\hline Samples & Width $(\mathrm{mm})$ & Thickness $(\mathrm{mm})$ & Area $\left(\mathrm{mm}^{2}\right)$ & Notch $(\mathrm{mm})$ & $\begin{array}{l}\text { Energy } \\
(\text { Ft Lb) }\end{array}$ & Energy $(\mathrm{J})$ & Average Energy $(\mathrm{J})$ \\
\hline 1 & 14.5 & 6.2 & 89.9 & 5.5 & 8.0 & 10.85 & 10.53 \\
\hline 2 & 15.5 & 6.2 & 96.1 & 5.5 & 7.5 & 10.17 & \\
\hline 3 & 15.7 & 6.2 & 97.3 & 5.5 & 7.8 & 10.58 \\
\hline
\end{tabular}

Table 5b: Impact strength results for the OA welding

\begin{tabular}{|c|c|c|c|c|c|c|c|}
\hline Samples & Width (mm) & Thickness (mm) & Area $\left(\mathrm{mm}^{2}\right)$ & Notch (mm) & $\begin{array}{l}\text { Energy } \\
\text { (ft lb) }\end{array}$ & Energy $(J)$ & Average Energy (J) \\
\hline 1 & 15.2 & 6.2 & 94.24 & 5.5 & 4.5 & 6.10 & 6.46 \\
\hline 2 & 15.9 & 6.2 & 98.58 & 5.5 & 5.0 & 6.78 & \\
\hline 3 & 15.8 & 6.2 & 97.96 & 5.5 & 4.8 & 6.51 & \\
\hline
\end{tabular}

\subsection{Vickers Hardness Analysis (Hv)}

The hardness properties for the both welding methods are presented in Tables 6 (a) and (b). The TIG weldment had an average hardness value of $511 \mathrm{Hv}$, while the Oxy-Acetylene weldment had an average hardness value of $399 \mathrm{Hv}$. The TIG weldment has good indentation resistance, whereas the OA weldment has poor indentation resistance.

Table 6a: Hardness results for the TIG welding

\begin{tabular}{|llllll|}
\hline S/N & Specimen & $\mathbf{1}^{\text {st }}$ Indentation (Hv) & $\mathbf{2}^{\text {nd }}$ Indentation (Hv) & 3 $^{\text {rd }}$ Indentation (Hv) & Average Indentation (Hv) \\
\hline 1 & Parent metal & 508 & 527 & 499 & 510.3 \\
\hline 2 & HAZ & 490 & 502 & 514 & 502 \\
\hline 3 & Weldment & 514 & 514 & 505 & 511 \\
\hline
\end{tabular}

Table 6b: Hardness results for the OA welding

\begin{tabular}{|c|c|c|c|c|c|c|}
\hline $\mathrm{S} / \mathrm{N}$ & Specimen & $1^{\text {st }}$ Indentation (Hv) & $2^{\text {nd }}$ Indentation $(\mathrm{Hv})$ & $3^{\text {rd }}$ Indentation (Hv) & Average Indentation $(\mathrm{Hv})$ & Hv = Vicker's hardness value \\
\hline 1 & Parent Metal & 379 & 244 & 531 & 386.7 & Gross cracking occurred at plate \\
\hline 2 & HAZ & 379 & 264 & 443 & 393.7 & $\begin{array}{l}\text { hardness of } 510 \mathrm{HV} \text { or above for } \\
\text { ballistic performance of carbon }\end{array}$ \\
\hline 3 & Weldment & 404 & 266 & 527 & 399 & steel welded joints against 7.62 \\
\hline
\end{tabular}

assemblies suffered from HAZ with a hardness greater than 500 HV [33]. Where there are no welds, Edwards and Mathewson concluded that an improvised armour can be made from a viable tool steel if the hardness is kept to $380 \mathrm{HV}$, and better improvised armours could be formed from other saleable low-alloy steel plates of lower carbon material, heat treated to $380 \mathrm{HV}$, where welding would be easier [33]. As a result, in this study, TIG welding with hardnesses of $510.3,502$, and 511 for parent metal, HAZ, and weldment can be used to weld armour plate bodies to provide protection for the troops. 
(1) The TIG welding process has been found to provide the best resistance in the HAZ zone.

(2) The impact energy of the TIG weldment is similar to that of the parent metal (control), indicating that TIG welding has a greater weldment toughness to absorb projectile impact than OA welding.

(3) The micrography of the TIG weldment revealed a small coarse grain size of ferrite and bigger patches of pearlite at x200 magnification. Wider HAZ's OA welding method is anticipated to have poor ballistic performance.

\section{Declarations}

\section{Funding statement}

This research did not receive any specific grant from funding agencies in the public, commercial, or not-for-profit sectors.

\section{Acknowledgements}

The authors acknowledge the Mechanical Engineering Department Nigerian Defence Academy, PMB 2109 Kaduna, Nigeria, Mechanical Engineering, at Ahmadu Bello University, Zaria, 810212 Samaru Zaria, Kaduna State, Nigeria, and Defence Industries Corporation of Nigeria (DICON) for providing facilities to carry out this study. In addition, we acknowledge the support of Staff of the Mechanical Department of the Research and Development, DICON.

\section{Data availability}

The data and materials in this manuscript came from the test and calculation as reported in the manuscript.

\section{Conflict of Interest Statement}

We, the authors of the manuscript titled "Mechanical and Micrography Analysis of Armour Plate Weldment Using Tungsten Inert Gas and Oxy-Acetylene Welding Methods", hereby wish to submit the manuscript for your kind attention. We hereby declare no conflict of interest.

\section{References}

[1] Bhaduri AK, Albert SK, Ray SK, Rodriguez P. Recent trends in repair and refurbishing of steam turbine components Sadhana 3(2003) 395408. https://doi.org/10.1007/BF02706440.

[2] Jindal S, Rahul C, Mehta NP. Investigation on flux design for submerged arc welding of high-strength low-alloy steel. Proceedings of the Institution of Mechanical Engineers, Part B: J Eng Manufact 227(2013) 383-395. https://doi.org/10.1177/0954405412468993.

[3] Nanavati P K. Studies on Effect of Welding Parameters on Corrosion and Mechanical Behaviour of Duplex Stainless-Steel Welds. PhD diss., Maharaja Sayajirao University of Baroda (India), 2018.

[4] Ade F. Ballistic qualification of armor steel weldments. Welding Journal 70(1991) 53-58.

[5] Crouch IG. Metallic Armor-form Cast Aluminum alloys to High-Strength Sheets. In Materials Forum 12(1988) 31-37. NII Article ID (NAID):80004503385.

[6] Maweja K, Stumpf W. The design of advanced performance high strength low-carbon martensitic armour steels: Microstructural considerations. Materials Science and Engineering: A 480(2008) 160-6.

https://doi.org/10.1016/j.msea.2007.07.078.

[7] Jena PK, Kumar KS, Krishna VR, Singh AK, Bhat TB. Studies on the role of microstructure on performance of a high strength armour steel. Engineering Failure Analysis 15(2008) 1088-96. https://doi.org/10.1016/j.engfailanal.2007.11.011.

[8] Hu CJ, Lee PY, Chen JS. Ballistic performance and microstructure of modified rolled homogeneous armor steel. J Chinese Institute of Engineers. 25(2002) 99-107. https://doi.org/10.1080/02533839.2002.9670684.

[9] Sangoy L, Meunier Y, Pont G. Steels for ballistic protection. Israel journal of technology 24(1988) 319-26.

[10] Reddy GM, Mohandas T, Papukutty K. Enhancement of ballistic capabilities of soft welds through hardfacing. Inter J Impact Eng 22(1999) 77591. https://doi.org/10.1016/S0734-743X(99)00020-2.

[11] Reddy GM, Mohandas T, Papukutty KK. Effect of welding process on the ballistic performance of high-strength low-alloy steel weldments. $J$ Maters Process Tech 74(1998) 27-35.

https://doi.org/10.1016/S0924-0136(97)00245-8

[12] Reddy GM, Mohandas T. Ballistic performance of high-strengh low-alloy steel weldments. J Maters Process Techn 53(1996) 23-

30. https://doi.org/10.1016/0924-0136(95)02041-1. 
[13] Mohandas T, Reddy GM, Kumar BS. Heat-affected zone softening in high-strength low-alloy steels. J Maters Process Tech 88(1999) 28494. https://doi.org/10.1016/S0924-0136(98)00404-X.

[14] Lundin CD, Gill TP, Qiao CY. Heat affected zones in low carbon microalloyed steels. ASM International. 2(1990) 249-56.

[15] Mazuera Robledo D, Suarez Gomez JA, Giraldo Barrada JE. Development of a welding procedure for mil a 46100 armor steel joints using gas metal arc welding. Dyna. 78(2011) 65-71.

Print version ISSN 0012-7353On-line version ISSN 2346-2183

[16] Richmond O, Morrison HL, Devenpeck ML. Sphere indentation with application to the Brinell hardness test. Inter J Mech Sci 16(1974) 75-

82. https://doi.org/10.1016/0020-7403(74)90034-4.

[17] Choudhary S, Singh PK, Khare S, Kumar K, Mahajan P, Verma RK. Ballistic impact behaviour of newly developed armour grade steel: An experimental and numerical study. Inter J Impact Eng 140(2020) 103557. https://doi.org/10.1016/j.jimpeng.2020.103557.

[18] Banerjee A, Dhar S, Acharyya S, Datta D, Nayak N. Determination of Johnson cook material and failure model constants and numerical modelling of Charpy impact test of armour steel. Maters Sci and Eng: A 640(2015) 200-9. https://doi.org/10.1016/j.msea.2015.05.073.

[19] Barsom JM, Rolfe ST. Correlations between K IC and Charpy V-notch test results in the transition-temperature range. In Impact testing of metals 1970. ASTM International. DOI: 10.1520/STP32067S

[20] ASTM American Society for Testing and Materials. Standard test methods for tension testing of metallic materials. ASTM international 2009.

[21] Chen C, Zeng S, Su L. Strain energy based method for metal magnetic memory effect of tensile tested structures. J Nondestructive Evaluation 38(2019) 1-2. https://doi.org/10.1007/s10921-019-0579-4

[22] Mathers G. Mechanical Testing-Notched Bar or Impact Testing. The Welding Institute 2016.

[23] Boumerzoug Z, Derfouf C, Baudin T. Effect of welding on microstructure and mechanical properties of an industrial low carbon steel. Engineering. 2(2010) 502. doi:10.4236/eng.2010.27066

[24] Grange RA. The rapid heat treatment of steel. Metallurgical transactions 2(1971) 65-78.

https://doi.org/10.1007/BF02662639

[25] Digges TG, Rosenberg SJ, Geil GW. Heat treatment and properties of iron and steel. NATIONAL BUREAU OF STANDARDS GAITHERSBURG MD; 1966. Accession Number:ADA361141.

[26] Rao GK, Panchanathan V. Application of chills to the production of sound castings. Production Engineer 53(1974) 79-84. DOI: 10.1049/tpe.1974.0021

[27] Laible RC. Ballistic Materials and Penetration Mechanics. Amer J Forensic Med and Path. 3(1982) 190.

[28] Roylance D, Wang SS. Penetration mechanics of textile structures. Access Number:ADA089445

[29] Gurjar BR, Van Aardenne JA, Lelieveld J, Mohan M. Emission estimates and trends (1990-2000) for megacity Delhi and implications. Atmospheric Environment 38(2004) 5663-81.

https://doi.org/10.1016/j.atmosenv.2004.05.057

[30] Dikshit SN, Kutumbarao VV, Sundararajan G. The influence of plate hardness on the ballistic penetration of thick steel plates. Inter $\mathrm{J}$ Impact Eng 16(1995) 293-320. https://doi.org/10.1016/0734-743X(94)00041-T

[31] Sorensen BR, Kimsey KD, Silsby GF, Scheffler DR, Sherrick TM, De Rosset WS. High velocity penetration of steel targets. Inter J Impact Eng 11(1991) 10719. https://doi.org/10.1016/0734-743X(91)90034-D.

[32] Hani AR, Roslan A, Mariatti J, Maziah M. Body armor technology: a review of materials, construction techniques and enhancement of ballistic energy absorption. In Advanced Materials Research 488(2012) 806-812). https://doi.org/10.4028/www.scientific.net/AMR.488-489.806.

[33] Edwards MR, Mathewson A. The ballistic properties of tool steel as a potential improvised armour plate. Inter J Impact Eng 19(1997) 297-

309. https://doi.org/10.1016/S0734-743X(97)83210-1.

[34] Maweja K, Stumpf W. Fracture and ballistic-induced phase transformation in tempered martensitic low-carbon armour steels. Maters Sci and Eng: A 432(2006) 158-69.

https://doi.org/10.1016/j.msea.2006.06.033

[35] Bhadeshia HK. Carbon content of retained austenite in quenched steels. Metal Sci 17(1983) 151-2. https://doi.org/10.1179/030634583790421087

Page 8/11 
Figures
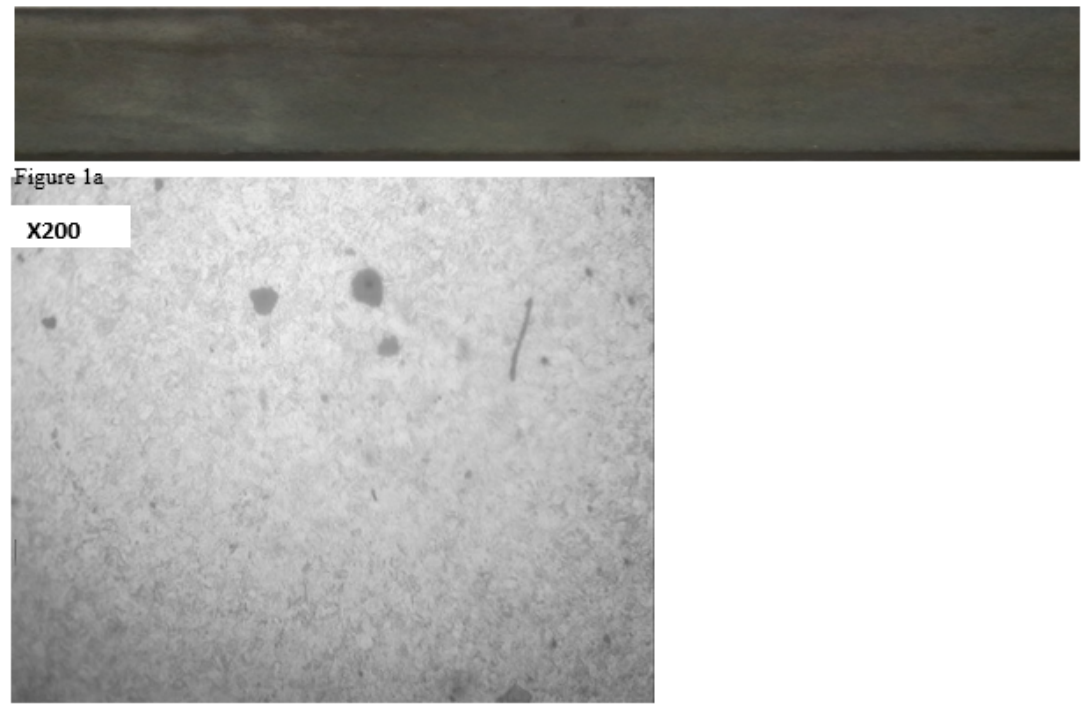

Figure 1b

Figure 1

a: Parent Metal

$\mathrm{b}$ : Microstructure of the parent metal

\section{$(x)$}

Figure 2a

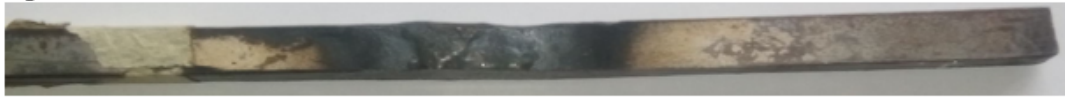

Figure $2 b$

Figure 2

a: Oxyacetylene method welded joint

b: Tungsten method welded joint 

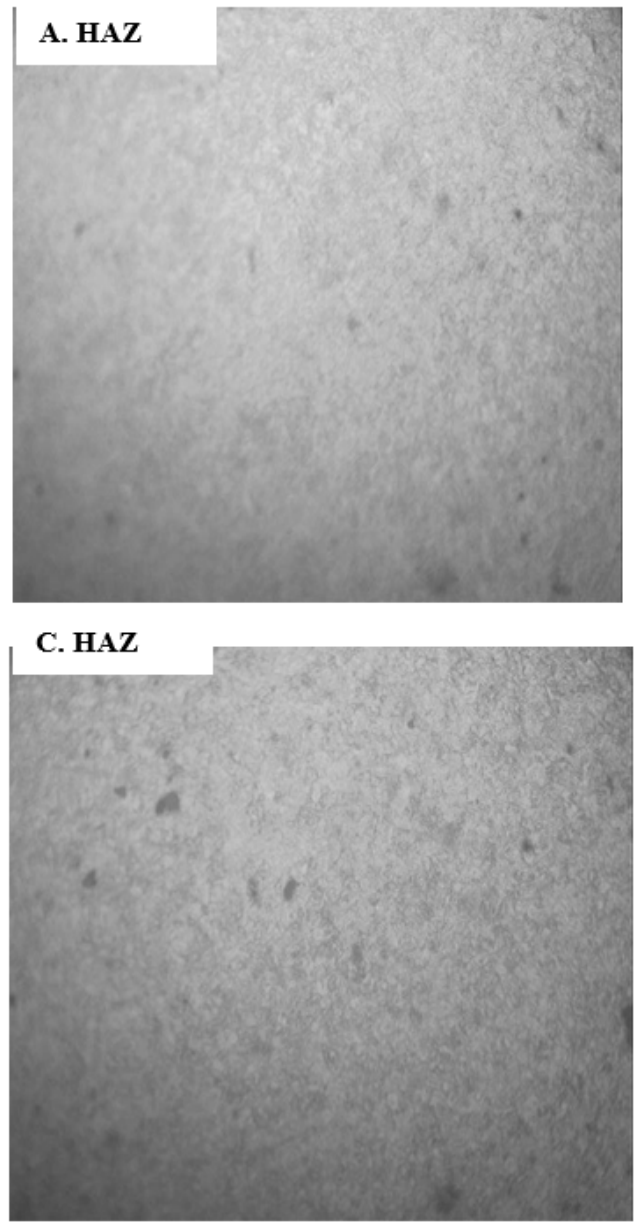

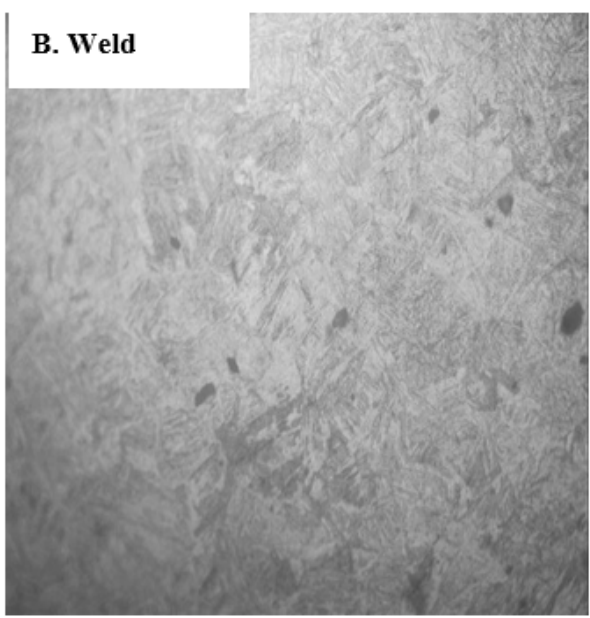

D. Weld

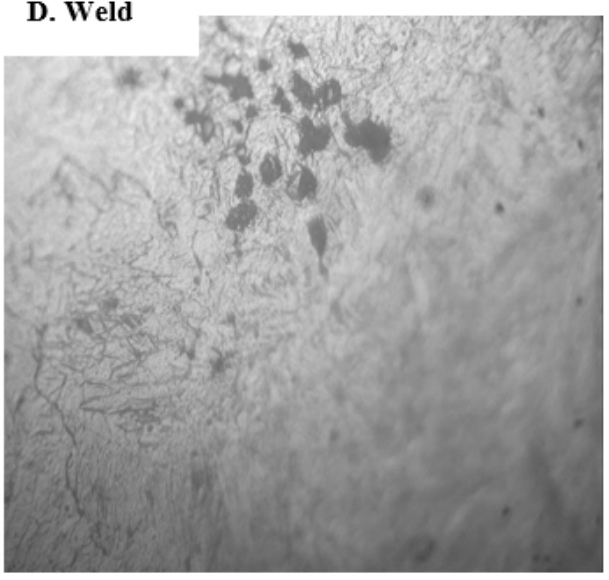

\section{Figure 3}

(A) Micrography of TIG weld HAZ (B) Micrography of TIG weld joint

(C) Micrography of OA weld HAZ (D) Micrography of OA weld joint

a

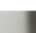

b
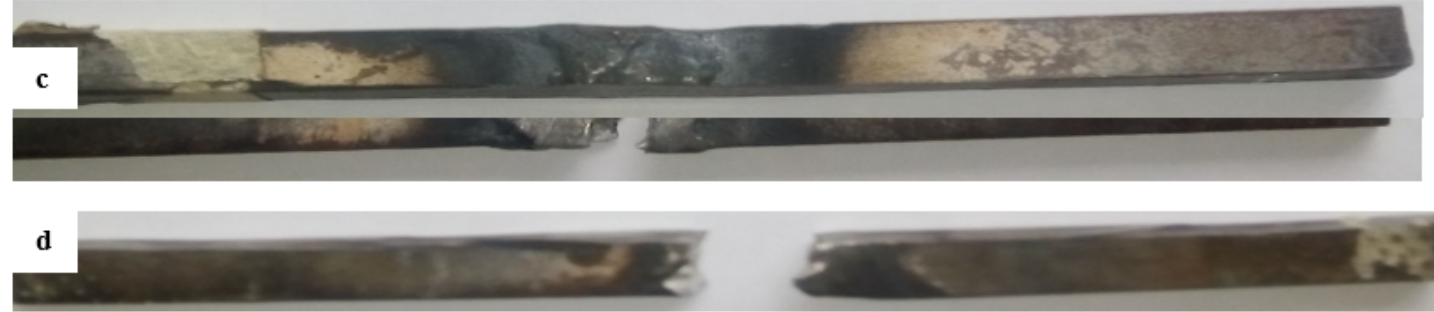

Figure 4

(a) Welded joint of OA welding, (b) Welded joint of TIG welding, (c) tensile test structure of OA welding and (d) tensile test structure of OA welding 


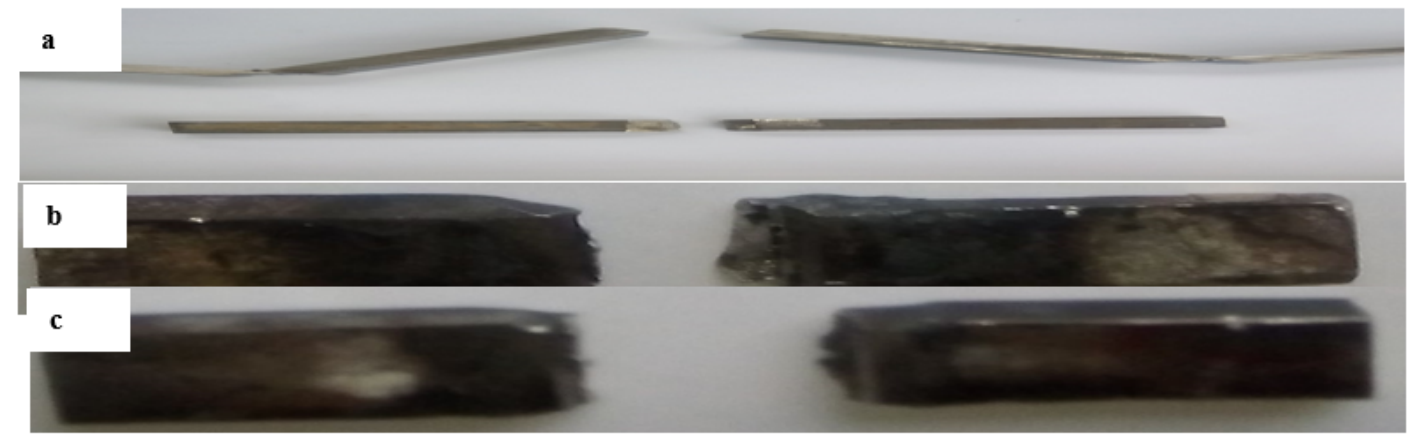

\section{Figure 5}

(a) Impact behaviour of the parent metal, (b) Impact behaviour of the TIG welding, (c) Impact behaviour of the OA welding
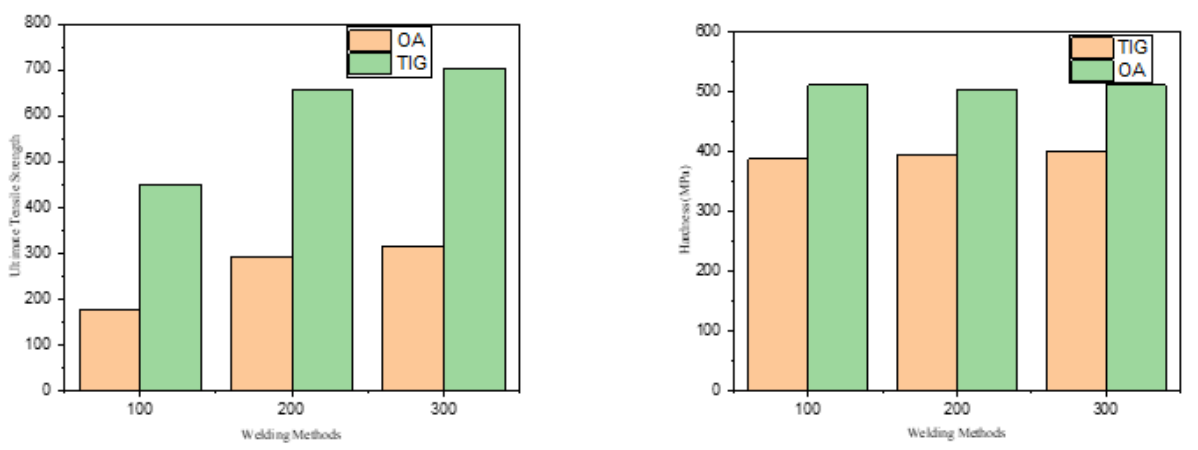

\section{Figure 6}

Mechanical testing comparison (a) Ultimate tensile strength (b) Vickers Hardness 